\section{Walking along the river-front in Kansai}

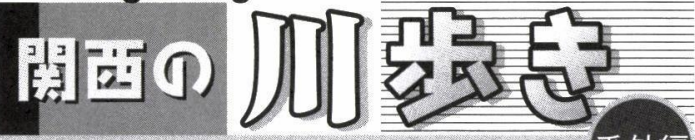

番外編

2004年の 4 月に開始した連載では，これまでに 関東の「いたち川」, 韓国の「清渓川」を挟んで, 合計14本の川辺を歩いたことになります。ここに はこれまで歩いた14の川の写真を 1 枚ずつ掲載し

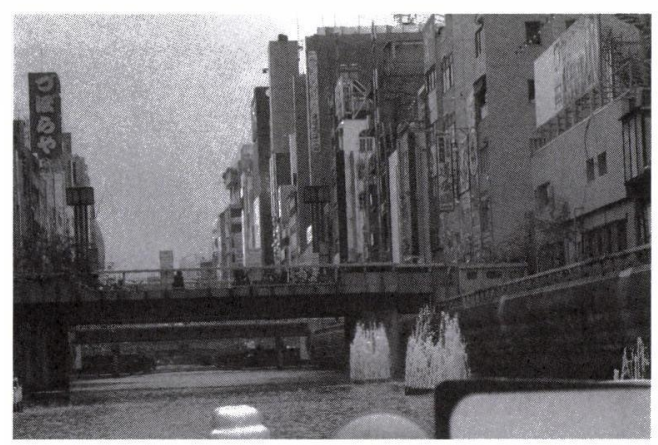

04.4月号 No.1 東横堀・道頓堀川「歓楽街を流れる」

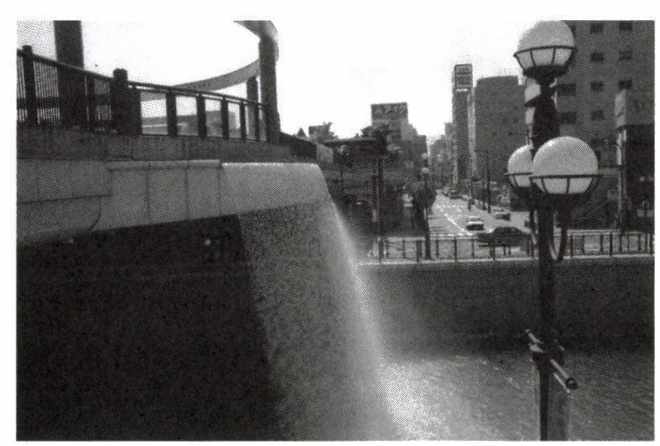

04.5月号 No.2 庄下川「下流部阪神尼崎駅付近」

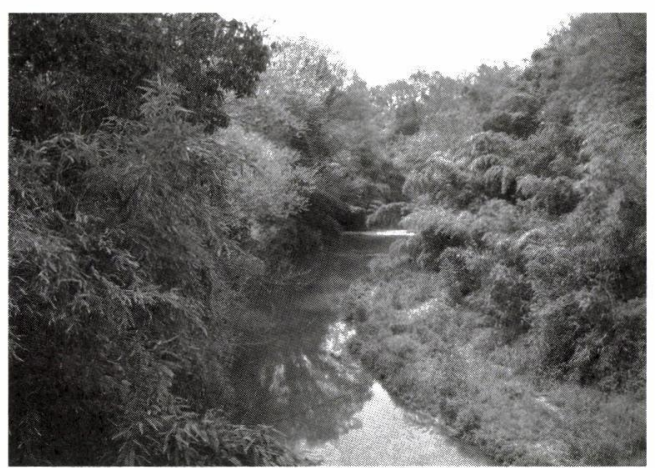

04.6月号 No.3 近木川「中流部の河畔林」
ています。

今月号は一休みして, 来月からまた歩き始めま す.9月号では，亀岡に端を発し上流部は攝津峡 で有名で，下流部は高槻市内を南北に縦断して淀 川に注ぐ芥川，10月号では，山科を通って明治以 来豊かな水量を京都へ運ぶ琵琶湖疎水を取り上げ ます。その後，滋賀県へ足を延ばして，丹生ダム を抱える湖北の高時川，また大津の川辺も歩く予 定でいます.

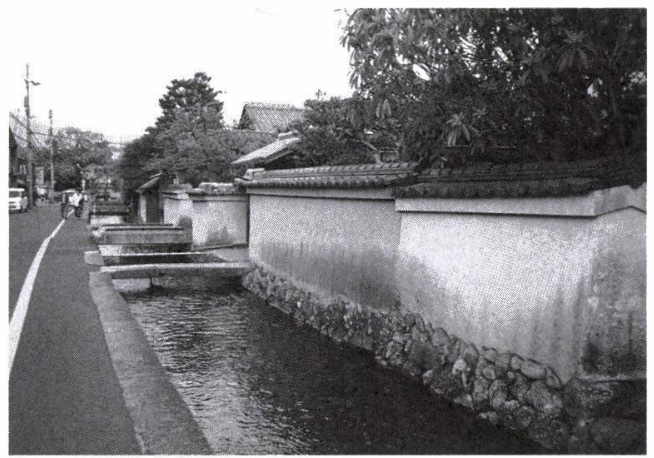

04.7月号 No.4 明神川「上賀茂の社家町付近」

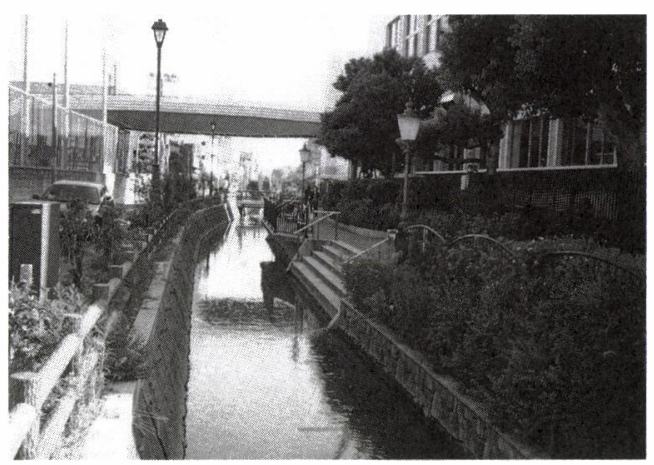

04.8月号 No.5 長瀬川「樟蔭学園付近」

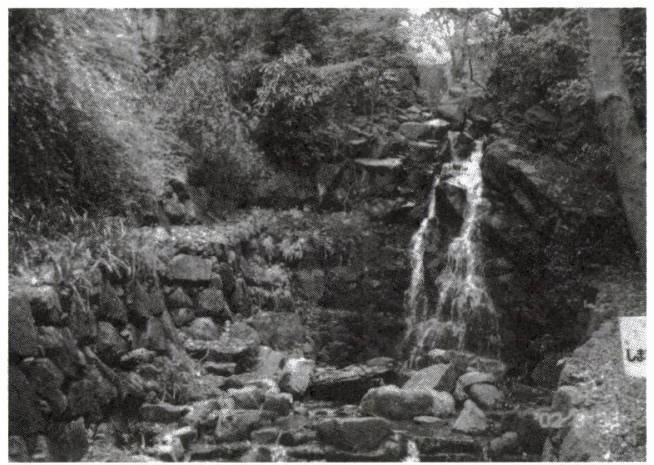

04.9月号 No.6 生駒の川と恩智川「豊浦川」 


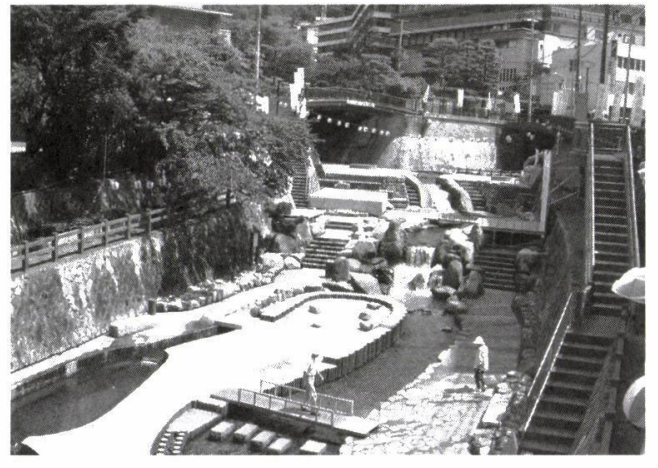

04.10月号 No.7 有馬川「有馬駅付近の親水公園」

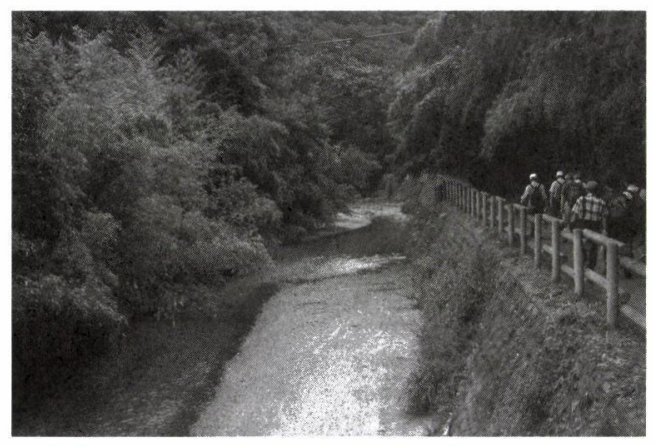

04.12月号 No.9 天野川「中流部の木々とハイキング道」

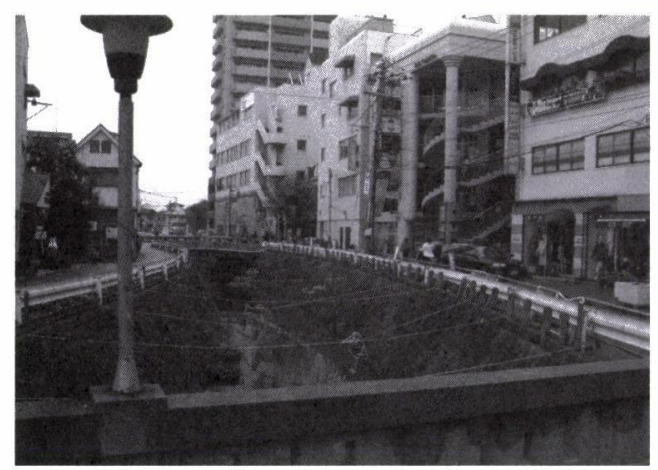

05.1月号 No.10 津門川「阪急西宮北口駅付近」

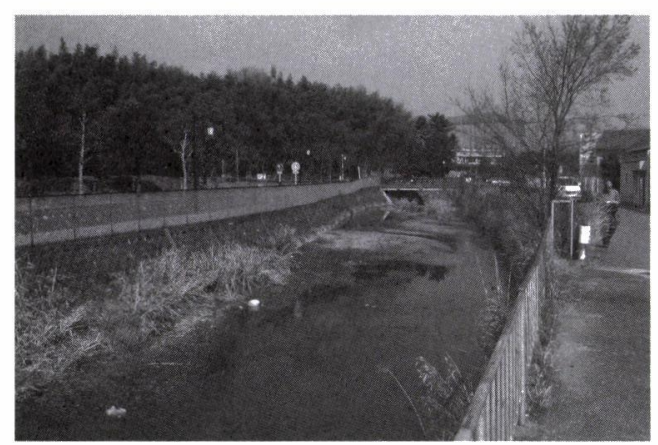

05.2月号 No.11 寝屋川北部「上流部深北緑地付近」

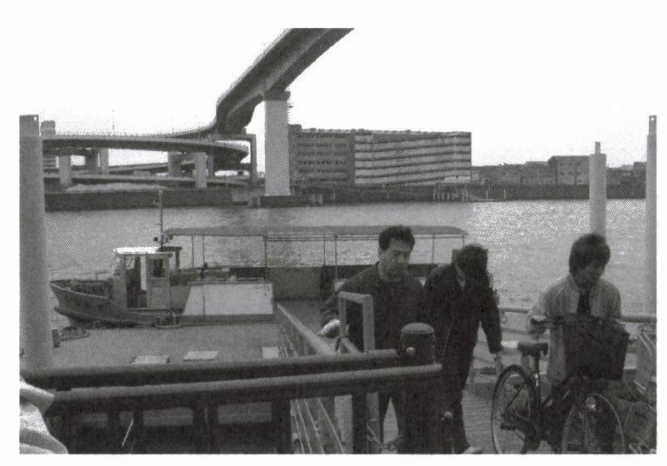

05.3月号 No.12「渡し」「木津川河口と千本松渡し」

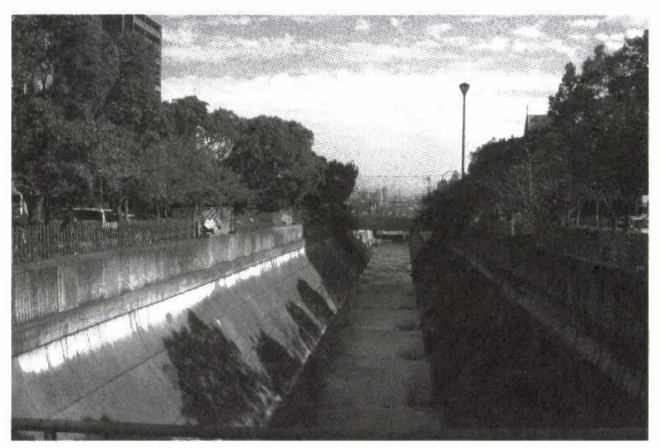

05.4月号 No.13 生田川「下流部新神戸駅南側」

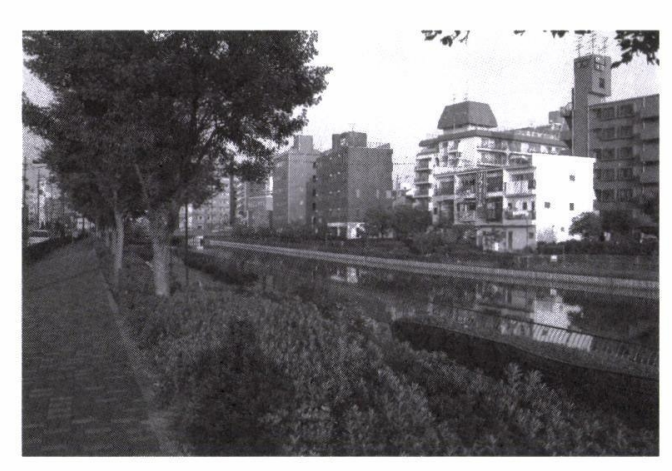

05.5月号 No.14 土居川・内川「堺市の中心を流れる」

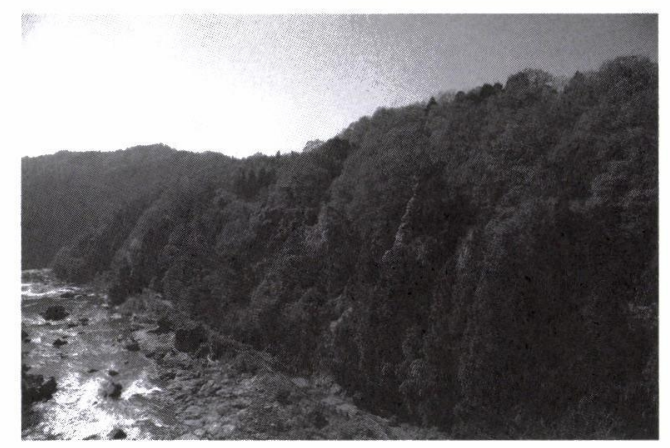

05.6月号 No.15 木津川「岩倉峡狭窂部」 